\title{
South African Bibliography: A Review
}

\author{
By REUBEN MUSIKER
}

The yeAR 1962 ushered in a new phase of bibliographical activity in South Africa. The National Conference of Library Authorities, which was held in Pretoria in November of that year, may be regarded as the culmination of three years of activity in the cause of library cooperation. The resolutions ${ }^{1}$ of the conference are bound to have a profound effect on the course of bibliography in South Africa, and the time is therefore opportune to survey bibliographical developments up to the present.

In the review which follows the criteria employed are similar to those which D. H. Borchardt applied in his survey of Australian bibliography, published in an earlier issue of $C R L .{ }^{2}$ The present review is limited to being a guide to a basic list of references on South Africa with comprehensiveness of treatment as the prime basis of selection.

Accounts of bibliographical progress in South Africa have appeared regularly in South African Libraries, which is the official organ of the South African Library Association. These annual, and sometimes biennial, reviews give a firstrate account of progress in such bibliographical projects as union catalogs, directories of resources, catalogs of special collections, and inventories of manuscript collections. Bird's-eye views of bibliographical developments have been provided in two decennial surveys by $R$. L.

1 National Conference of Library Authorities, Pretoria, 5th-6th November 1962. Programme for Future Library Development in the Republic of South Africa. Potchefstroom: South African Library Association, 1963. Reprinted from South African Libraries, XXX (January 1963), 77-117.

D. H. Borchardt, "Australian Bibliography: an Assay." CRL, XXIII (May 1962), 207-212, 251-54.
Mr. Musiker is Deputy Librarian, Rhodes University, Grahamstown, South Africa.

\section{Collison $^{3}$ and O. H. Spohr. ${ }^{4}$}

The most important standard bibliography for the early period is Sidney Mendelssohn's South African Bibliography ${ }^{5}$ which attempted to record the known literature about South Africa of all periods and in all languages. The items recorded were either in Mendelssohn's own library, which is now in the possession of the Library of Parliament, or in other public and private libraries, or had been traced through booksellers' catalogs and other sources. It continues to be a basic and indispensable work. Since 1909, which is the terminal date of entries in Mendelssohn, there has been a vast accumulation of material published in and about South Africa, and it is unfortunate that no formal arrangements were made to revise the work. It is true that the work was supplemented on cards in the Mendelssohn library and for a time in the Library of Parliament's annual accessions list, ${ }^{6}$ but it was not until 1960 that steps were taken to implement a revision project. The aim is now to include all traceable material omitted from the 1910 edition, as well as corrections to material in Mendelssohn where the error is significant, and material published dur-

${ }^{3}$ R. L. Collison, Bibliographical Services Throughout the World, 1950-1959 (Paris: UNESCO, 1961), p. 135-38.

H. H. Spohr, "Technischer Fortschritt der Dokumentation in Südafrika in den Jahren 1952-1962." Nachrichten für Dokumentation, XIII (June 1962), 76-82.

s. Mendelssohn, South African Bibliography, 2 vols. (London: Kegan Paul, 1910). A facsimile reprint was published by Arco Publications, London, 1957.

'South Africa (Republic). Library of Parliament. Annual List of Africana Received [in the Mendelssohn library]; No. 1, 1938-No. 9, 1946. Cape Town: The Library, 1949-1948. 
ing the period 1909 to 1925 ; this latter date being chosen because of the steady improvement in South African documentation since then. The work of revision is being undertaken by the South African library, Cape Town, and to date more than twenty-three thousand items have been added to the seventy-five hundred entries in the 1910 edition.

Mendelssohn's Bibliography is essentially an author catalog, and there is but one subject bibliography of Africana which can complement it. This is the Subject Catalogue of the Royal Empire Society (now the Royal Commonwealth Society). ${ }^{7}$ It was published in 1930 but remains a most useful tool for bibliographical information up to that date. G. McC. Theal's Catalogue of Books and Pamphlets Relating to Africa South of the Zambesi ${ }^{8}$ is still of considerable historical interest. A useful book to consult for family papers is Una Long's Index to Authors of Unofficial Privately Owned Manuscripts Relating to the History of South Africa, 1812-1920.9

South Africa has long been famous as a port of call for travellers, and there is consequently a considerable body of travel literature. N. H. Mackenzie's South African Travel Literature in the Seventeenth Century ${ }^{10}$ includes a bibliography up to 1700 . The period since then has only been partially covered in various bibliographies, and a comprehensive bibliography of twentieth-century travel literature commends itself as a desirable project for the future.

Two exhibition catalogs issued to commemorate national anniversaries are acknowledged as important bibliographies

\footnotetext{
T Royal Empire Society. Subject Catalogue of the Library . . . by P. Evans Lewin (London, The Society, 1930). I: British Empire generally and Africa.

8 G. McC. Theal, Catalogue of Books and Pamphlets Relating to the Africa South of the Zambesi (Cape Town: Cape Times, 1912).

${ }^{\circ} \mathrm{U}$. Long, $A n$ Index to Authors of Unofficial, Privately-Owned Manuscripts Relating to the History of South Africa, 1812-1920 (London: Lund Humphries, 1947).

${ }^{10}$ N. H. Mackenzie, South African Travel Literature in the 17th Century. Archives Yearbook for South African History. 1955 , v. 2, p. 1-112.
}

of Africana. While emphasizing literary and linguistic material they also cover a wide variety of other topics. South Africa in Print ${ }^{11}$ was published in 1952 to commemorate the arrival of Jan van Riebeeck at the Cape on April 6, 1652, while The Book in South Africa was issued to mark the fiftieth anniversary of the Union of South Africa. ${ }^{12}$ A bibliography of Africana which provides an interesting link with the United States of America is E. A. Brett's Tentative List of Books and Pamphlets Published in the United States of America and Canada. ${ }^{13}$ It includes approximately five hundred fifty items of American Africana.

South Africa has two national libraries: the State library, Pretoria, which functions as the national lending library, and the South African library, Cape Town, which serves as the national reference library. Both libraries have issued regular lists of accessions, the State library since 1933 and the South African library since 1946 , based on material received by legal deposit under the terms of the Copyright Act No. 9 of 1916. In 1958 the South African library, and in 1959 the State library commenced publishing full-scale national bibliographies. While there is some degree of duplication between these two tools, there is also at least one major difference, in that the South African National Bibliography, ${ }^{14}$ which is published by the State library, is restricted to material published in South Africa, whereas Africana Nova, ${ }^{15}$ which is published by the South African

\footnotetext{
11 Van Riebeeck Festival, 1952. Book Exhibition Committee. South Africa in Print: Catalogue of an Exhibition of Books, Atlases and Maps Held in the South African Library, Cape Town, March-April 1952 (Cape Town: The Committee, 1952).

12 Union Festival, 1960. Book Exhibition, Bloem. fontein. The Book in South Africa: Exhibition of South African Publications, 9.31/V/1960 (Bloemfontein: Union Festival Committee, 1960).

${ }^{13}$ E. A. Brett, Tentative List of Books and Pamphlets on Southern Africa Published in the United States and Canada (Johannesburg: Public Library, 1959).

14 S.A.N.B.: South African National Bibliography, 1959- (Pretoria: State Library, 1960-).

${ }_{15}$ Africana Nova: a Quarterly Bibliography of Books Currently Published in and about the Republic of South Africa, No. 1, September 1958- (Cape Town:
} South African Public Library, 1958-). 
library, includes books and pamphlets about South Africa published abroad. In this way the two works succeed in complementing each other, and it may be said that they do indeed fulfill the basic functions of current national bibliography.

Coverage of the period prior to 1959 is incomplete. The South African Catalogue of Books ${ }^{16}$ attempted, though imperfectly, to record works published from 1900 to 1950 . With a view to filling the gaps, the National Conference of Library Authorities, 1962, has recommended that the State library should undertake the publication of a cumulative retrospective bibliography for the pre-1959 period.

Among other current bibliographical tools, two warrant mention here. $A B i b$ liography of African Bibliographies Covering Territories South of the Sahara ${ }^{17}$ has been published since 1942 and has now established itself as the standard work on its subject. The fourth edition, compiled by A. M. Lewin Robinson, was published early in 1961 and contains approximately thirteen hundred fifty entries. It is supplemented between main revisions in the Quarterly Bulletin of the South African Library. A work which does for South Africa what Constance Winchell's Guide to Reference Books accomplishes for a wider audience has been published since 1955 and is now in its third edition. This is the Guide to South African Reference Books, compiled by $\mathrm{R}$. Musiker. ${ }^{18}$ It is an annotated list of over five hundred key reference works on South African topics.

South African periodical literature has

16 South African Catalogue of Books, 4th complete edition, 1900-1950, 2 vols. (Johannesburg: [Technibooks], 1950).

17 South African Public Library, Cape Town. A Bib. liography of African Bibliographies, Covering Territories South of the Sahara, 4th edition, revised to November 1960; compiled by A. M. Lewin Robinson (Cape Town: The Library, 1961) Grey Bibliographies, No. 7.

${ }^{18} \mathrm{R}$. Musiker, Guide to South African Reference Books, 3d revised edition (Grahamstown: Rhodes University Library, 1963). been well documented since 1940. A guide to the contents of more than two hundred South African periodicals is provided by the Index to South African Periodicals. ${ }^{19}$ Decennial cumulations have been published for 1940-1949 and 1950-1959, followed by annual volumes thereafter. The period prior to 1940 remains uncovered, but here too there is hope that a resolution of the National Conference of Library Authorities, 1962, will, if implemented, remedy this defect. South Africa also now has a compact union list of periodicals, entitled Periodicals in South African Libraries, ${ }^{20}$ which represents possibly the greatest cooperative achievement in South African library history. It is modeled on Scientific Serials in Australian Libraries, is being issued letter-by-letter in looseleaf form, and is subject to continuous revision. This will supersede, when complete, an earlier union catalog compiled by P. Freer.

Bibliographies of official publications are included in the current national bibliographies referred to earlier in this review. An important cumulative index to government publications for the period from 1910 to 1961 was published in February $1963 .{ }^{21}$ The standard bibliography on South African law is A. A. Roberts's South African Legal Bibliography. ${ }^{22}$ Current bibliographical coverage of law has been provided since 1947 in the Annual Survey of South African Law. ${ }^{23}$

University research is comparatively

${ }^{19}$ Index to South African Periodicals, 1940/1949(Johannesburg: Public Library, 1953-).

${ }^{20}$ Periodicals in South African Libraries: a Revised Edition of the Catalogue of Union Periodicals (Pretoria: South African Council for Scientific and Industrial Research and National Council for Social Research, 1961-).

${ }^{2}$ South Africa (Republic). House of Assembly. Index to the Manuscript Annexures and Printed Papers of the House of Assembly, Including Select Committee Reports and Bills and Also to Principal Motions and Resolutions and Commission Reports, 1910-1961 (Pretoria: Government Printer, 1963).

2 A. A. Roberts, South African Legal Bibliography: Being a Bibliographical Survey and Law-Finder of the Roman and Roman-Dutch Legal Literature in South Africa (Pretoria: Wallach, 1942).

${ }^{23}$ Annual Survey of South African Law, by the Faculty of Law, University of the Witwatersrand, 1947- (Cape Town: Juta, 1948-). 
well documented. Two major union lists cover the period from 1918 to 1958 . A. M. Lewin Robinson's Catalogue of Theses and Dissertations Accepted for Degrees by the South African Universities ${ }^{24}$ covers the period from 1918 to 1941 , while S. I. Malan $^{25}$ has compiled a list of similar scope for the period from 1942 to 1958. Potchefstroom University keeps this work up-to-date by means of annual supplements. Current university research is recorded bibliographically in the Register of Current Scientific Work at South African Universities, ${ }^{26}$ which is published annually. There is also an equivalent work for the humanities. ${ }^{27}$ In addition, South African universities issue research reports giving an account of work in progress and listing publications by staff members.

One of the few general scientific bibliographies of South Africa is that found in E. B. Worthington's Science in the Development of Africa. ${ }^{28}$ The Council for Scientific and Industrial Research fulfills an important function in providing current bibliographies of scientific writings by means of several tools. Its semiannual Research Review ${ }^{29}$ includes lists of all articles and reports published under the auspices of the C.S.I.R., while its monthly Library Information and $\mathrm{AC}$ cessions $^{30}$ is also a useful tool published in a versatile format. It is beyond the

24 A. M. Lewin Robinson, Catalogue of Theses and Dissertations Accepted for Degrees by the South African Universities, 1918-1941 (Cape Town, The Author, 1943).

${ }^{25}$ S. I. Malan, Union Catalogue of Theses and Dissertations of the South African Universities, 1942-1958 (Potchefstroom: Potchef stroom University, 1959)

${ }^{2}$ Register of Current Scientific Research at South African Universities, No. 1- (Pretoria: South African Council for Scientific and Industrial Research, 1951-).

${ }^{27}$ Register of Current Research in the Humanities at the Universities, No. 1- (Pretoria: National Council for Social Research, 1949-).

${ }^{28} \mathrm{E}$. B. Worthington, Science in the Development of Africa: a Review of the Contribution of Physical and Biological Knowledge South of the Sahara (London: Commission for Technical Cooperation in Africa South of the Sahara and Scientific Council for Africa, 1958).

${ }^{29}$ CSIR Research Review. Vol. 1- (Pretoria, South African Council for Scientific and Industrial Research, 1951-).

so South African Council for Scientific and Industrial Research. Library Information and Accessions. Vol. 1(Pretoria, The Council, 1960- ). scope of this review to mention more than a few outstanding examples of subject bibliographies in science. A. J. H. Goodwin's Loom of Prehistory, ${ }^{31}$ I. Schapera's Select Bibliography of South African Native Life and Problems, 32 and A. L. Hall's Bibliography of South African Geology $y^{33}$ are all standard works in their fields.

For the field of South African letters, the Cambridge Bibliography of English Literature, ${ }^{34}$ which covers South African material from 1789 to 1914 , provides a good starting point. Two indigenous works of value are M. Nathan's South African Literature ${ }^{35}$ and E. R. Seary's Biographical and Bibliographical Record of South African Literature in English. ${ }^{36}$ Current coverage is provided by the bibliographies which appear from time to time in the South African P. E. N. Year Book $^{37}$ and in English Studies in Africa. ${ }^{38}$ A bibliography of more specific scope covering the South African novel in English from 1800 to 1930 has also been published. ${ }^{39}$ P. J. Nienaber has compiled a comprehensive bibliography of books in the Afrikaans language. ${ }^{40}$ Lists of translated works published in South Africa are compiled by the State library for in-

${ }^{31}$ A. J. H. Goodwin, The Loom of Prehistory: a Commentary and a Select Bibliography of the Prehistory of Southern Africa (Cape Town: South African Archaeological Society, 1946).

${ }^{22}$ I. Schapera, Select Bibliography of South African Native Life and Problems (London: Oxford University Press, 1941).

${ }^{3}$ A. L. Hall, Bibliography of South African Geology to 1935, 6 vols. (Pretoria: Government Printer, 19221939).

34 Cambridge Bibliography of English Literature, ed. by F. W. Bateson (Cambridge: Cambridge University Press, 1940), vol. 3, p. 1088-93, and Supplement vol., 1957, p. 707-08.

${ }^{35}$ M. Nathan, South African Literature: a General Survey (Cape Town: Juta, 1925).

${ }^{36} \mathrm{E}$. R. Seary, A Biographical and Bibliographical Record of South African Literature in English (Grahamstown: The Author, 1938).

${ }^{3}$ South African P.E.N. Year Book, 1954- (Johannesburg: South African Centre of the International P.E.N. Club, 1954-).

ss English Studies in Africa, vol. 1- (Johannesburg: Witwatersrand University Press, 1958-).

J. P. L. Snyman, A Bibliography of South African Novels in English (Potchefstroom: Potchefstroom University, 1951).

to P. J. Nienaber, Bibliografie van Afrikaanse Boeke, April 1861/April 1943- (Johannesburg: The Author, 1943-). 
Subject bibliographies in other fields have increased copiously in recent years. Much good work has been done by postgraduate students in librarianship at South African universities in fulfilment of courses which require the compilation of a bibliography under supervision. Many subjects which would otherwise not have been covered bibliographically have been done in this way. These and all other important subject bibliographies are listed in the Bibliography of African Bibliographies mentioned previously.

There are still many lacunae to be

41 Index Translationum: repertoire internationale des Traductions, new series, vol. 1, 1948- (Paris: UNESCO, 1949- ).

\section{Flying Buttresses or Vending Machines?}

MORE AND MORE we find that goals based on our best estimates of future developments tend, in a few short years, to be outdistanced by an overambitious and often disrespectful reality. . . . While cost figures presented by the Council on Library Resources for books vs. microfilm make excellent sense in a general way, and while it is comforting to those who must plan ahead for library facilities to know that the codex is something to be counted on, there are still certain specific areas where rather radical changes in format are both possible and probable. . . Far too little has changed in academic library work since the thirteenth century. . . . We are still at the stage of the old medieval builder . . . who constructed flying buttresses by trial and error, piling on far more stones than were ever necessary. When the forms were removed he would stand back (at a good distance), put his fingers in his ears, shut his eyes and hope for the best. . . . In the general academic library, we are still at the stage of piling on more and more volumes....

Since most of the newly-developed machinery for information control depends heavily on numerical volume for its effectiveness, average mean circulation figures preclude such machinery from general academic libraries for some years to come. Not so . . . for the high-use portions of an undergraduate library. . . . The reduction of standard undergraduate collections to microcards has been under way for some time, and it now appears that the development of a practical reader is nearing completion. ... The possible effects of microcard vending machines in college libraries would be tremendous. For one thing, the "Reserve Book Room" as we know it would disappear. . . . But, as with all other such innovations, in order to be most effective, it must be additive and not replacive. Were such a possibility to become a reality ... it would not change the number of volumes on the shelves. It would certainly change the ratio of titles to volumes, however. Duplication of titles could be reduced by over eighty per cent, and still the student would have freer access and longer access to the materials he uses most often. At the same time, the undergraduate collection could be a richer, more varied source for other types of reading.-Floyd M. Cammack, "Goals for the 60's," Hawaii Library Association Journal, Spring 1963. 